\title{
Turmoil and strife abound
}

Paris

THE science and technology programmes of the United Nations Educational, Scientific and Cultural Organization (Unesco) are putting a brave face on the threatened withdrawal of the United States at the end of the year. Indeed, there is even a possibility that for the next few months, science and technology, which have often been pleaded in aid in the past year, will be more generously dealt with.

One sign of this is that the annual grant to the International Council of Scientific Unions has been increased by a quarter to $\$ 500,000$ for the year ahead, exclusive of contracts yet to be agreed. But Unesco's generosity will also take in for the first time the World Federation of Scientific Workers, which is to receive $\$ 5,000$ or more to support its newsletter.

How the total funds for science and technology will be affected will be known only when the urgent review of the budget now under way is decided, in early April. The management has asked for a 10 per cent reduction, but this will not be equally spread. Much the same will happen to vacancies as they arise. Posts will be left vacant if possible but otherwise filled by transfers within Unesco.

Much change is in prospect. The much respected head of the Man and Biosphere Programme left earlier this month for the University of Montpellier. The Belgian head of the Science Policy Division, the work of which was criticized at the biennial General Assembly last year (particularly by the British), will retire later this year. It will be a test of Unesco's managers' mood to see whether that vacant post is filled. One other senior departure seems in the offing at least, but there is talk of a senior Soviet scientist joining.

The mood among the staff ranges from optimism to despair. Some see the directorgeneral's attitude as intransigent, fear their life's work is being jeopardized - "It's just as much my Unesco as his" - and fear that prospects of promotion are blocked. Others consider that less money may encourage efficiency and point out that their financial contribution to outside activities such as training is often only token and could be further reduced without catastrophe.

Some administrative problems are as yet unsolved. For many collaborative projects, the United States provides not only its general contribution but also assistance in kind - research vessels, communications and administration. So will US agencies be allowed (or wish) to continue if withdrawal goes ahead?

The charge of bureaucracy levelled at Unesco is impossible to verify or deny. Some say it is a mess, others point out that repeated enquiries from member governments make endless work, as do the endless

committee meetings at which a Unesco presence is thought necessary. More worrying are the sudden if small shifts of policy at the behest of top management or if an itinerant official should rashly promise to help a host government.

\section{US medical schools Admissions coaching challenged}

\section{Washington}

THE administrators of the standard test for admission to US medical schools are taking new legal action to prevent a Pennsylvanian company from using bootlegged copies of past tests. The Association of American Medical Colleges (AAMC), which owns the standard Medical College Admission Test, or MCAT, charged in federal court last week that Multiprep, a company that offers to prepare students for MCAT, had reproduced questions from the tests verbatim in its course materials in violation of copyright law.

Multiprep is one of many small organizations offering coaching courses for students planning to take college admissions tests, such as MCAT, that tend to weigh heavily in admissions decisions. The test administrators' standard line has been to discount the effectiveness of such courses, which typically cost several hundred dollars, but otherwise to view them as a tolerable nuisance.

Last June, however, AAMC noticed that 250 students from the Philadelphia area who took MCAT in April 1983 did particularly well on questions that had been recycled from the test given in autumn 1980. Further investigation revealed that all had taken the Multiprep course. AAMC obtained a court order to have Multiprep's offices raided; on the basis of materials seized by federal marshals in the raid, including exact copies of MCAT question papers, AAMC was then granted a temporary injunction against Multiprep pending a trial on the merits of the copyright violation charge. The injunction specifically barred Multiprep from using MCAT materials or from advertising, as it had, its possession of "facsimile" MCAT tests.

In last week's action, AAMC claimed that Multiprep had violated the court order on both counts. AAMC said that 77 of the 87 chemistry and biology questions appearing in Multiprep's current course materials were word-for-word copies of MCAT questions.

According to AAMC, questions are " often" repeated from year to year in the test both for statistical reasons and because of the limited number of "quality", questions covering first-year college material in biology, chemistry and physics. The test administrators take pains to prevent the circulation of test questions;
One impression is that Unesco's most serious problem in science and technology is that it expects its staff to behave as scientists when they are administrators, that the organization is as a result too ready to make judgements off its own bat without the benefit of external advice, and that the endless search for programmes that sound well often blinds it to projects it could usefully tackle. question papers are numbered serially and are collected and checked after each administration of the test. AAMC officials believe that Multiprep obtained their material by having an examinee remove the inner pages of a test booklet, replacing them with dummy pages.

No date has been set for the trial on AAMC's original accusation of copyright infringement, in which AAMC is seeking $\$ 1.5$ million in damages against Multiprep. Stephen Budiansky

\section{Accident casualties}

Romania's Minister of the Chemical Industry, Gheorghe Caranfil, and his deputy, Ion Bivoralu, were sacked last week as a result of a major accident last December in the pyrolysis installation at the Teleajen petrochemical combine. A joint party and government commission found that the accident was due to "serious deficiencies" in the organization and management of the pyrolysis installation during its commissioning, violations of safety regulations and "serious violations" of order and discipline. The Communist Party Secretariat of Prahova County (in which the Teleajen plant is situated) was rebuked for failing to take "appropriate political educational measures" to ensure the smooth operation of the plant, and the first secretary of the county party committee, Virgil Cazacu, and also a deputy prime minister, Ion Nicolae, received votes of censure.

No details of the accident have been published, but the tone of the official announcements, with their repeated use of the words "grave" and "serious", as well as the penalties imposed, point to major human and financial loss.

The petrochemical industry is a particularly sensitive issue in Romania. Mrs Elena Ceaucescu, the wife of the party leader, is herself a petrochemical engineer, and, as head of the National Council for Science and Technology, was responsible for the expansion of Romania's petrochemical capacity in the early 1970s - a programme which caused Romania, an oil-producer, to become a net oil importer, and which has been a major cause of the country's present energy problems.

Vera Rich 